\title{
BUDAYA TORAJA DALAM PEMBELAJARAN BAHASA INDONESIA
}

\author{
DAHLIA PATIUNG \\ Fakultas Tarbiyah dan Keguruan \\ Universitas Islam Negeri Alauddin Makassar
}

\begin{abstract}
:
This study aims to examine in depth about the application of Toraja cultural values in learning Indonesian language in North Toraja District. The method used in this research is descriptive qualitative method. In the data collection, researchers directly involved observing the phenomena that occur in Indonesian language learning in North Toraja State Senior High School. Technique of data collection is done by observation, recording, documentation, and interview. Data analysis was done by data flow model analysis technique. The results showed that the application of Toraja cultural values in Indonesian language learning in SMA Toraja has built the values of Kasiuluran (kinship), tengko situru '(togetherness), kabassaran (work ethic), sikamali' (love), kapa patonganan (religious), siri '(shame), and the value menghangkegi'to mendadianna (devotion children to parents).
\end{abstract}

Keywords: Cultural Value, Language Learning.

\section{PENDAHULUAN}

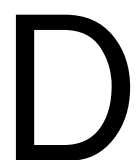

i dalam kehidupan sehari-hari betapa pentingnya peranan bahasa sebagai alat komunikasi. Manusia telah ditakdirkan satu sama lain memerlukan pertolongan untuk memelihara, meningkatkan dan mempertahankan kehidupannya. Pertolongan itu pertama-pertama diperoleh dengan bantuan bahasa. Andaikata manusia hidup seorang diri, tidak berkelurga, tidak mempunyai sahabat, maka tidak akan ada bahasa. Sepanjang pengetahuan manusia tidak pernah hidup seorang diri, melainkan selalu hidup berkelompok betapapun kecil dan sederhananya karena manusia adalah makhluk sosial. Dalam hal ini jelaslah bahwa peran bahasa sangan penting dalam kehidupan bermasyarakat.

Jadi bahasa adalah lambang berupa bunyi yang dihasilkan oleh alat ucap manusia yang mempunyai sistem dan mengandung arti yang dipakai manusia dalam kehidupannya sebagai alat komunikasi antarsesamanya untuk membentuk, mengungkapkan dan menyampaikan pikiran serta perasaan sesuai dengan yang dikehendakinya.

Pendidikan karakter adalah memfasilitasi penguatan dan pengembangan nilainilai tertentu sehingga terwujud dalam perilaku peserta didik, baik ketika proses sekolah maupu setelah proses sekolah (setelah lulus dari sekolah). Penguatan dan pengembangan memiliki makna bahwa pendidikan di sekolah bukanlah sekedar suatu dogmatisasi nilai kepada peserta didik, tetapi sebuah proses yang membawa peserta didik untuk memahami dan merefleksi bagaimana suatu nilai menjadi penting untuk diwujudkan dalam perilaku keseharian. Penguatan mengarahkan proses pendidikan pada proses pembiasaan yang disertai oleh logika dan refleksi 
terhadap proses dan dampak dari proses pembiasaan yang dilakukan di kelas maupun di sekolah sehingga berdampak pada proses pembiasaan rumah. Dengan demikan, maka asusmsi dari tujuan ini adalah mencapai tujuan penguatan dan pengembangan karakter.

Nurcholish Madjid (2000:4) berpendapat bahwa manusia bukan saja makhluk religius tetapi juga makhluk budaya. Artinya kebudayaan merupakan ukuran dalam hidup dan tingkah laku manusia, baik sebagai makhluk individu maupun sebagai makhluk sosial. Indonesia dalam sejarah dikenal sebagai suatu bangsa yang plural heterogen dan multikultural yang ditandai dengan adanya perbedaan ras, etnis, klasifikasi sosial seperti budaya dan agama, dan stratifikasi sosial. Perspektif sosiologi dan antropologi hal ini adalah suatu keniscayaan dalam sistem masyarakat yang akan memberikan warna dan nuansa dinamis dalam kehidupan manusia baik dalam lingkup sederhana maupun lingkup yang kompleks (Al Munawwar: 89).

Pendapat M. Atho Mudzhar (2001:127), bahwa masyarakat Indonesia adalah masyarakat majemuk, baik dalam skop nasional maupun daerah. Kemajemukan itu bersifat multi dimensional, ada yang ditimbulkan oleh perbedaan suku, tingkat sosial, pengelompokan organisasi politik, agama dan sebagainya.

Manusia menciptakan budaya dan lingkungan sosial sebagai adaptasi terhadap lingkungan fisik dan biologisnya. Kebiasaan-kebiasaan, praktik dan tradisi diwariskan dari generasi ke generasi. Pada gilirannya generasi tersebut terkondisikan menerima nilai budaya yang diwariskan oleh manusia terdahulu sebagai standar perilaku dalam menata kehidupan secara individu maupun sebagai anggota masyarakat.

Orientasi pembelajaran bahasa Indonesia adalah kemampuan dan keterampilan siswa menggunakan bahasa Indonesia dalam berbagai tujuan dan kebutuhan baik dalam konteks sosial maupun pengkajian dan penerapan ilmu pengetahuan. Untuk mengemban tujuan ini, pembelajaran bahasa harus dilaksanakan secara integratif antara pengetahuan bahasa dan keterampilan berbahasa.

Syafi'ie (1984), menyatakan bahwa tujuan pembelajaran bahasa berupaya mengembangkan komunikasi siswa. Dengan demikian, perhatian guru harus lebih dipusatkan kepada penggunaan bahasa untuk maksud komunikatif. Siswa dibimbing untuk dapat menggunakan bahasa bukan sekadar mengetahui tentang bahasa. Pembelajaran bahasa dengan pendekatan komunikatif secara utuh bukan semata-mata membentuk kompetensi kebahasan.

Orientasi pembelajaran bahasa berdasarkan Kurikulum bahasa Indonesia 2006 adalah kemampuan dan keterampilan siswa menggunakan bahasa Indonesia dalam berbagai tujuan dan kebutuhan, baik dalam konteks sosial maupun pengkajian dan penerapan ilmu pengetahuan. Untuk mengemban tujuan ini, pembelajaran bahasa harus dilaksanakan secara integratif antara pengetahuan bahasa dan keterampilan berbahasa. Pengetahuan dalam rangka pengembangan 
bahasa Indonesia menjadi "bahasa ilmu pengetahuan", dan keterampilan berbahasa yang diisyarati oleh berbagai aspek sosiokultural akan mengangkat bahasa Indonesia menjadi “bahasa yang berbudaya” (Tolla, 1996: 13).

Salah satu fungsi bahasa adalah sebagai alat komunikasi, yaitu alat untuk menyampaikan gagasan, pesan, perasaan, pikiran, pendapat, dan sebagainya. Oleh karena itu, berlainan dengan pendekatan struktural yang menyajikan materi berupa butir-butir tata bahasa berdasarkan suatu urutan dari struktur yang sederhana ke struktur yang kompleks. Para pembelajar mula-mula diperkenalkan dengan bunyibunyi, bentuk-bentuk kata, struktur kalimat, kemudian makna-makna unsur-unsur tersebut. "Dalam pendekatan komunikatif bahan pelajaran tidak disusun atas dasar satuan-satuan gramatikal, tetapi atas dasar fungsi-fungsi komunikatif, dengan memperhatikan faktor-faktor seperti siapa yang berbicara dengan siapa, untuk maksud dan tujuan apa, dalam situasi dan konteks apa, dalam peristiwa apa, dan melalui jalur apa.

Pembelajaran bahasa Indonesia lebih banyak menekankan pengetahuan bahasa dan berorientasi pada gramatika karena adanya anggapan yang keliru, yaitu kita pada umumnya sudah memiliki kemampuan atau keterampilan berbahasa dengan baik dan benar. Oleh karena itu, hal yang perlu dipelajari dan diajarkan di sekolah adalah pengetahuan dan teori bahasa. bukan keterampilan berbahasa.

Apa yang diperlukan oleh anak didik dan orang yang merasa dapat berbahasa Indonesia adalah kemampuan menyatakan perasaan dan pikiran dengan bahasa Indonesia yang baik dan benar, secara lisan maupun tulisan. Baik dalam arti sesuai dengan konteks sosial budaya dan tujuan saat bahasa tersebut digunakan dan benar karena sesuai dengan kaidah-kaidah tata bahasa yang baku. Diajarkan di sekolah saat ini lebih menekankan penggunaan bahasa yang benar dan kurang mengutamakan penggunaan bahasa yang baik.

Di dalam GBPP Kurikulum bahasa Indonesia 2006 dinyatakan bahwa belajar bahasa pada hakikatnya adalah belajar berkomunikasi. Oleh karena itu, Pembelajaran bahasa Indonesia diarahkan kepada peningkatan kemampuan siswa dalam berkomunikasi dengan menggunakan bahasa Indonesia, baik secara lisan maupun tulis.

Atas dasar uraian tersebut, penelitian ini diarahkan untuk membahas budaya Toraja dalam pembelajaran Bahasa Indonesia.

\section{METODE PENELITIAN Jenis Penelitian}

Jenis yang digunakan adalah penelitian kualitatif dengan rancangan deskripsi. Rancangan ini digunakan sesuai dengan rumusan masalah dan tujuan penelitian sebagaimana dikemukakan pada bagian awal. 


\section{Fokus Penelitian}

Sugiono (2010: 285) berpendapat bahwa pandangan penelitian data kualitatif adalah gejala bersifat holistik (menyeluruh, tidak dapat dipisah-pisahkan), sehingga peneliti data kualitatif tidak akan menetapkan penelitiannya hanya berdasarkan hasil penelitian, tetapi keseluruhan situasi sosial yang teliti, yaitu memiliki aspek tempat, dan aktivitas yang berinteraksi secara sinergi.

\section{Definisi Operasional}

Pembelajaran bahasa yang menerapkan prinsip-prinsip kompetensi komunikatif dan berorientasi kepada tujuan belajar bahasa untuk meningkatkan pengetahuan dan keterampilan berbahasa untuk tujuan-tujuan tertentu seperti menyapa, meminta maaf, menasihati, memuja atau mengungkapkan pesan tertentu dalam kegiatan berkomunikasi.

\section{Desain Penelitian}

Kegiatan ini menggunakan rancangan penelitian deskriptif kualitatif. Penerapan deksriptif kualitatif dalam penelitian didasarkan atas pertimbangan kajiannya yang berusaha mengamati dan mendekripsikan segala fenomena yang terjadi pada objek penelitian tanpa memberikan perlakuan dan pengendalian terhadap subjek penelitian seperti dalam penelitian eksperimen.

\section{Data dan Sumber Data}

\section{a. Data Penelitian}

Data yang dimaksud dalam penelitian ini adalah keterangan atau bahan nyata yang dapat dijadikan dasar kajian (analisis) atau kesimpulan.

\section{b. Sumber Data}

Sumber data dalam penelitian ini adalah siswa dan guru SMA Negeri Kabupaten

Toraja Utara. Sumber data diperoleh dari kegiatan belajar-mengajar.

\section{Instrumen Penelitian}

Dalam pengumpulan data, peneliti sendiri terlibat secara langsung mengamati segala fenomena alamiah yang terjadi dalam pembelajaran bahasa Indonesia khususnya aspek keterampilan berbicara di SMA Negeri Toraja Utara.

\section{Teknik Pengumpulan Data}

Pada pengumpulan data penulis menggunakan teknik observasi, wawancara, perekaman dengan tablet, dalam proses belajar-mengajar dan dokumentasi.

\section{Pemeriksaan Keabsahan Data}

Pengecekan keabasahan data penelitian dilakukan dengan cara:

a. Mengadakan pengamatan dengan tekun dan seksama,

b. Melakukan triangulasi dengan cara membandingkan pembelajaran bahasa Indonesia dan kondisi objektif di lapangan. 
c. Mengadakan diskusi dengan teman sejawat dan guru bidang studi bahasa Indonesia maupun dengan doktor dan guru besar yang ada relevansi keilmuan dengan penelitian tersebut.

\section{Teknik Analisis Data}

Data yang dikumpulkan dianalisis dengan menggunakan prosedur Analisis Data Model Alir dengan cara menata secara sistematis catatan hasil observasi kelas dan hasil wawancara. untuk melakukan kegiatan ini ditempuh prosedur (1) Reduksi data, (2) Penyajian data, dan (3) Penarikan kesimpulan. Rangkaian kegiatan ini dikerjakan secara simultan dan terus-menerus, baik analisis data di lapangan maupun analisis data yang dikerjakan setelah penelitian rampung (Tolla, 1996: 215).

\section{PEMBAHASAN}

Pembelajaran bahasa Indonesia di SMA Negeri Kabupaten Toraja Utara erat kaitannya dengan nilai-nilai sosial kehidupan masyarakat Toraja Utara yaitu:

\section{Nilai Kasiuluran (Kekeluargaan)}

Melalui pembelajaran di kelas khususnya pembelajaran bahasa Indonesia dari aspek keterampilan berbicara, guru bahasa Indonesia selalu meekankan siswanya untuk tetap menjaga kebersamaan dan kekeluargaaan melalui bahasa. Sebagaimana pada pembahasan tema kedua Sehat dengan Berolahraga guru ketika menjelaskan materi pada saat itu juga guru bahasa Indonesia mengatakan misa' kada dipotuo, pantan kada dipomate artinya satu kata kita teguh/kuat, berbeda kata kita hancur. Pesan ini menekankan bahwa siswa sebagai bagian masyarakat, tetap menjaga aspek hubungan baik antara keluarga jangan karena persoalan harta lalu menjadi penyebab terjadinya perselisihan antara anggota keluarga, tetapi bagaimana agar hubungan keluarga selalu berdasarkan kepada keutuhan terciptanya keluarga yang harmonis.

Di sini peneliti menyimpulan bahwa dalam proses pembelajaran guru selalu mengajarkan nilai-nilai sosial kehidupan masyarakat Toraja Utara melalui pembelajaran bahasa Indonesia khususnya aspek keterampilan berbicara. Melalui pembinaan dan penggunaan bahasa secara terus-menerus akan menumbuhkan nilai-nilai kekeluargaan yang lebih baik.

Implementasi nilai-nilai kekeluargaan dalam kehidupan masyarakat Toraja Utara yang terbentuk dalam sikap perilaku keseharian, dapat menciptakan harmonisasi kehidupan dalam kehidupan keluarga dan masyarakat. Nilai kasiuluran (kekeluargaan) di Toraja Utara sejalan dengan sistem pendidikan nasional tahun 2003 tentang pendidikan yang berbasis karakter salah satunya nilai bersahabat/komunikatif yaitu tindakan yang memperlihatkan rasa senang berbicara, bergaul, dan bekerja sama dengan orang lain. 


\section{Nilai Tengko Situru' (Kebersamaan)}

Nilai kebersamaan yang tercipta didalam proses pembelajaran melalui pembentukan kelompok, siswa bekerja sama mengerjakan tugas melalui diskusi, mereka merespon pekerjaan kelompok yang lain jika diminta guru. Berdasarkan pengamatan peneliti di kelas pada pembahasan tema kedua (pemanasan global), melalui artikel didalam buku paket bahasa Indonesia untuk SMA/MA, dengan penggunaan bahasa Indonesia yang baik dan benar. Selanjutnya guru memberi contoh saya mau pergi melihat kerbau yang diadu di sawah besok pagi, kemudian siswa diminta untuk menerjemahkan kedalam bahasa Toraja.

Berdasarkan contoh yang diberikan guru tersebut mencerminkan bahwa orang Toraja pada umumnya masih sangat terikat dengan budaya, salah satunya budaya rambu solo', sehingga di dalam dunia pendidikan khususnya di sekolah guru selalu mengaitkan kehidupan masyarakat Toraja dengan lingkungan sekolah. Sebagaimana contoh yang diberikan guru tersebut saya mau pergi melihat kerbau yang diadu di sawah besok pagi, kalimat ini mencerminkan bahwa masyarkat Toraja menjunjung tinggi nilai kebersamaan dalam hidup bermasyarakat dipupuk dan dibina secara harmonis dengan kesediaan berkorban dan menolong dengan sukarela dan sepenuh hati mempersembahkan kerbau pagi keluarganya dalam pelaksanaan upacara rambu solo'. Kesediaan berkorban (potong kerbau) akan melahirkan kepekaan sosial yang dapat bermanfaat kepada sesama manusia, kemudian masyarakat turut berpartisipasi membantu dalam pelaksanaannya.

Implementasi nilai-nilai kabassaran (kebersamaan) dalam kehidupan masyarakat Toraja Utara terbentuk dalam sikap perilaku keseharian, bahkan sampai pada situasi pendidikan salah satunya pendidikan disekolah kabassaran (kebersamaan) sejalan sistem pendidikan nasional yang berbasis karakter, salah satu nilai karakter adalah bersahabat /komunikatif yaitu tindakan yang memperlihatkan rasa senang berbicara, bergaul, dan bekerja sama dengan orang lain.

Proses pembelajaran keterampilan berbicara di kelas implementasi bahwa orang Toraja bergaul dan bekerja sama dengan orang lain, bahwa dalam pembahasan materi siswa lebih banyak berdiskusi. Tugas yang diberikan oleh guru lebih banyak melibatkan siswa dalam mengerjakan tugasnya secara berkelompok. Melalui kerja kelompok tersebut siswa lebih kreatif, mandiri, bekerja sama dengan kelompoknya dan lebih menghargai pendapat temannya.

\section{Nilai Kabassaran (Etos Kerja)}

Nilai etos kerja juga tercermin melalui pembelajaran di dalam kelas. Siswa melakukan kegiatan berulang kali baik secara individu maupun kelompok untuk mendapatkan hasil yang maksimal mereka tidak berputus asa, mengatasi permasalahan dan kesulitan yang dihadapinya dengan tengan dikoreksi guru, sedangkan siswa mengerjakan ulang tugas sesuai petunjuk guru. 
Kegiatan siswa dikelas selalu terkait dengan budaya masyarakat Toraja sebagaimana yang sudah dipaparkan dalam nilai kabassaran (etos kerja), dengan memerhatikan contoh yang diberikan guru terlihat pada kalimat saya mau pergi melihat adu kerbau, misa' kada dipotuo pantan kada dipomate, (satu kata kita teguh/ kuat, berbeda kata kita hancur), turut pula mencerminkan bahwa sampai saat ini masyarakat Toraja masih sangat menjunjung budaya mereka. Mereka masih aktif dalam pelaksanaan upacara rambu solo', pelaksanaan upacara rambu solo' membutuhkan biaya yang sangat besar, sehigga mengharuskan masyarkat Toraja Utara bekerja keras agar dapat melaksanakan upacara. Pelaksanaan upacara rambu solo' layak menjadi harapan dan impian masyarakat Toraja pada umumnya, sekalipun mengeluarkan biaya yang sangat besar. Kondisi seperti ini mengharuskan masyarakat untuk bekerja keras sekalipun harus merantau ke negeri orang, oleh karena itu, kerja keras merupakan bagian motivasi untuk meraih prestasi. Nilai kabassaran (Etos Kerja), dalam hubungan pembelajaran di dalam kelas, bahwa siswa bekerja keras yaitu perilaku yang menunjukkan upaya sungguh-sungguh dalam mengatasi berbagai hambatan belajar dan tugas dengan sebaik baiknya.

Salah satu pilar sisdiknas dalam pendidikan karakter yaitu karakter bangsa bukan agresi perorangan, karena karakter bangsa harus terwujud dalam rasa kebangsaan yang kuat dalam konteks kultur yang beragama. Karakter bangsa mengandung perekat kultural yang terwujud dalam kesadaran kultural kecerdasan kultural setiap warga Negara. Mencermati pilar sisdiknas tersebut, maka efektifitas pendidikan karakter, sebaiknya dikembangkan melalui pendekatan terpadu dan menyeluruh melalui transformasi budaya dan kehidupan dilingkungan sekolah. Dengan demikian, melalui pendidikan karakter ini ditumbuh kembangkan pribadi anak didik menjadi pribadi yang utuh, terinternalisasikannya kebaikan dan terbiasa mewujudkan dalam kehidupan sehari-hari melalui penggunaan bahasa yang santun, bahasa yang bermartabat dalam mewujudkan bangsa yang bermartabat.

\section{Nilai Sikamali' (Kasih Sayang)}

Untuk mengaplikasikan prinsip-prinsip pendidikan karakter dalam proses pembelajaran, maka guru harus memahami perannya dalam mengembangkan nilainilai karakter. Dalam proses penjabaran siswa dituntun melalui pembiasaan untuk mengimplementasikan nilai-nilai karakter dalam semua kegiatan baik pada proses pembelajaran di dalam kelas maupun di luar kelas atau dilingkungan sekolah sebagai penjabaran dari nilai-nilai karakter yang didapatkan dalam proses pembelajaran.

Demikian pula situasi dan kondisi sekolah yang menjunjung tinggi persaudaraaan, sehingga tercipta hubungan yang harmonis pada seluruh warga sekolah agar perhatian dan kepekaan akan nilai-nilai moral yang harus ditegakkan di sekolah menjadi sesuatu yang harus mendapatkan waktu dan ruang yang cukup. 
SMA Negeri Toraja Utara setiap tahun setelah menamatkan siswanya, pada umumnya siswa melanjutkan pendidian ke perguruan tinggi dan lebih banyak melanjutkan pendidikan di luar Tana Toraja/Toraja Utara, mencari ilmu di luar daerah bahkan setelah menjadi sarjana mereka masih tetap merantau dalam rangka memperbaiki nasib mereka untuk mencari pekerjaan. Mencari rezeki di luar daerah, sampai tidak terasa waktu kalau ternyata mereka sudah terlalu lama tidak memberi kabar, tidak saling menyapa atau berkomunikasi, sudah terlalu lama tidak saling mengunjungi.

Nialai siakamali' (kasih sayang) menjadi bagian dari pesan orang tua pepasan to matua dalam masyarakat Toraja terhadap anak cucunya, pesan ini juga yang disampaikan guru bahwa jika kamu bepergian, maka ingatlah keluarga dan kampung kelahirannya. Pepasan to matua tersebut menekanan pada aspek jika seseorang bepergian ke negeri orang agar dapat beradaptasi dengan orang lain, memperbanyak komunikasi, bagaimana memperlakukan diri bagaikan ujung rumput artinya memiliki sifat yang rendah hati, tidak sombong, tidak melupakan kampung halaman sebagai kampung kelahirannya, jangan bagaikan hewan yang lupa keluarganya sehingga ia akan tersesat. Kata liar dapat ditafsirkan dengan ketidakmampuan beradaptasi dengan sesamanya, sehingga terpisahkan dari yang lainnya. Salah satu upacara orang Toraja Utara yang biasa mempererat nilai sikamali' (kasih sayang) adalah rambu solo' sebagai tempat aktualisasi diri membangun hubungan sosial baik antara keluarga maupun diantara masyarakat.

Keluarga masyarakat Toraja Utara yang pergi merantau, menjadi keharusan untuk pulang atau kembali ke Toraja Utara jika ada keluarga yang melaksanakan upacara rambu solo', karena suatu keinginan untuk saling melepas rasa rindu di antara keluarga. Kasih sayang yang terjaga baik dalam kehidupan masyarakat Toraja Utara sehingga keakraban dan kebersamaan dalam keluarga terpelihara dengan baik.

Nilai sikamali' (kasih sayang) tercermin dalam proses pembelajaran bahasa Indonesia dari aspek keterampilan berbicara berlangsung secara berkesinambungan melalui komunikasi yang terjadi antara guru dengan siswa, siswa dengan sesamanya dalam mengerjakan tugasnya secara berkelompok melalui diskusi. Melalui diskusi tercermin rasa saling menghargai dan menyayangi.

\section{Nilai Kapa'patonganan (Kerelegiusan)}

Pelaksanaan pendidikan karakter kapa'patonganan (kerelegiusan) Nampak melalui pembelajaran di dalam kelas maupun diluar kelas melalui pengintegrasian pembelajaran bahasa Indonesia khususnya aspek keterampilan berbicara dalam proses pembelajaran guru pada saat mengajar selalu menekankan siswa agar selalu menggunakan bahasa yang baik dan mengucapkan terimakasih jika mendapat kebaikan atau mendapat bantuan dari orang lain baik materil maupun moril menggunakan kata tolong atau tabe' jika memerlukan bantuan, mengucapkan kata 
maaf jika melakukan kesalahan. Selain itu siswa sebelum dan sesudah belajar mereka mengucapkan salam dan berdoa.

Pengintegrasian pendidikan berbasis karakter terhadap semua mata pelajaran, salah satunya adalah nilai religius. Di SMA Negeri Toraja Utara nilai relegius itu sangat tampak pada sikap dan perilaku guru dan siswa yang patuh dalam bertoleran terhadap pelaksanaan agama yang lain, dan hidup rukun dengan pemeluk agama lain yang ada di SMA Negeri Toraja Utara.

Mencermati tujuan pendidikan dalam sistem pendidikan nasional, menunjukkan bahwa pemerintah dan Negara sangat menyadari akan pentingnya nilai-nilai mora sebagai penguatan terhadap nilai-nilai relegius kepada peserta didik dalam kehidupan sehari-hari, sebagai upaya mewujudkan generasi yang cerdas dan memiliki integritas moral yang tinggi dalam menghadapi tantangan globalisasi, oleh karena itu prinsip pendidikan pada sistem pendidikan nasional, bahwa pendidikan diselenggarakan secara demokratis dan berkeadilan serta tidak diskriminatif dengan menjunjung tinggi hak asasi manusia, nilai keagamaan, nilai kultural, dan kemajemukan bangsa, sehingga tak ada lagi daerah dan warga Negara Indonesia yang terabaikan pendidikannya.

Pembelajaran keterampilan Indonesia merupakan salah satu aspek dalam pembelajaran bahasa Indonesia yang memiliki peran strategi dalam melaksanakan tujuan dari pendidikan nasional. Hal ini Nampak jelas tujuan dasar pembelajaran bahasa Indonesia di sekolah yakni mewujudkan warga negara yang baik melalui penggunaan bahasa yang baik dan benar dalam rangka penanaman nilai-nilai moral yang berkaitan dengan kebaikan dan keluhuran. Pembelajaran bahasa Indonesia khususnya aspek keterampilan berbicara secara implementatif melakukan upaya agar peserta didik memiliki sikap mental yang cerdas dan penuh rasa tanggung jawab baik secara horizontal sebagai makhluk sosial maupun hubungannya secara vertikal kepada sang khalik.

\section{Nilai Siri'/Longko' (Rasa Malu)}

Dalam rangka proses belajar mengajar guru menekankan juga pada aspek bersikap dengan kebenaran, karena sikap yang benar akan mendatangkan kebaikan bagi umat manusia. Konsep siri'/longko' (rasa malu) senantiasa menjadi dasar untuk bersikap sehingga sikap dan perilaku senantiasa terjaga dari kemaksiatan, sehingga melahirkan kehormatan dalam diri manusia.

Berdasarkan contoh kalimat yang diberikan guru Jangan menyontek pekerjaan teman! Secara tersirat kalimat ini bermakna jangan mengambil hak orang lain, bahwa manusia harus malu jika mengambil sesuatu yang bukan haknya, begitupun sebaliknya manusia merasa malu jika kewajibannya tidak dilaksanakan. Hal ini menggambarkan adanya rasa tanggung jawab yang harus dimiliki oleh siapapun.

Adapun keterkaitan nilai siri'/longko' (rasa malu) menjadi tidak malu dalam kegiatan belajar siswa, ketika mereka diminta guru untuk megemukakan 
pendapatnya melalui diskusi, tampil di depan-temanya misalnya pada saat membacaa teks wawancara, membaca puisi, mereka tidak kelihatan canggung bahkan sebaliknya mereka santai dan tidak gugup, bahkan mereka mampu menciptakan rasa optimis dan kepercayaan diri yang tinggi.

Kondisi pembelajran di kelas jika dihubungkan dengan kondisi masyarakat Toraja Utara pada umumnya bahwa salah satu nilai yang dikejar oleh masyarakat dalam pelaksanaan rambu solo' adalah siri' / harga diri /longko'. Harga diri atau longko' menyambut nama baik seseorang, keluarga, maupun persekutuan di dalam masyarakat orang Toraja Utara.

Konsep siri' dalam upacara rambu solo', jika diimplementasikan dalam kehidupan sosial masyarakat, bahwa masyarakat Toraja Utara sangat menghargai manusia sebagai ciptaan Tuhan yang paling mulia. Nilai manusia menempati posisi yang paling tinggi nilainya diantara makhluk-makhluk lainnya. Kesadaran nilai manusia dapat menghantarkan manusia untuk saling menghargai, menghormati, sehingga tercipta rasa kasih sayang dan hubungan yang harmonis antara umat manusia.

Rasa malu siri' ditunjukkan dengan nilai kejujuran yaitu siswa hendaknya berperilaku yang didasarkan pada upaya menjadikan dirinya sebagai orang yang selalu dapat dipercaya dalam perkataan, tindakan, dan pekerjaan melalui perkataan jangan pernah berbohong melalui tindakan atau sikap mana yang boleh dilakukan, begitupun dalam hal pekerjaan jangan pernah melalaikan tugas-tugas yang telah dibebakan oleh siapapun.

\section{Nilai Umpangke' To Mandadianna (Bakti Anak Kepada Orang Tua)}

Nilai umpangke' to mandadianna (bakti anak kepada orang tua), merupakan salah satu implementasi pendidikan yang berbasis karakter sebagai perwujudan cinta Tanah Air yaitu dengan cara berfikir, bersikap dan berbuat yang menunjukkan kesetiaan, kepedulian da penghargaaan yang tinggi terhadap bahasa. lingkungan fisik, sosial, budaya, ekonomi, dan politik bangsa.

Karakter yang baik yaitu mengetahui yang baik, menginginkan hal yang baik, dan melakukan hal yang baik. Menumbuhkan kebiasaan baik dalam cara berfikir, diperlukan untuk mengarahkan suatu kehidupan moral dalam rangka membentuk kebiasaan moral. Salah satu karakteristik kedewasaan moral adalah bagaimana siswa kepedulian yang tinggi terhadap lingkungan sosial termasuk ligkungan keluarga. Seorang anak diharapkan menghormati lingkungan keluarga (orang tua) maupun lingkungan sosial secara menyeluruh melalui kepedulian dan penghargaaan yag tinggi terhadap penggunaan bahasa yang santun. Penggunaan bahasa yang santun diperoleh dari lingkugan keluarga maupun melalui pembelajaran di sekolah.

Hal ini menunjukkan bahwa kesetiaan dan penghargaan terhadap bahasa tidak lahir begitu saja atau dengan tiba-tiba akan tetapi prosesnya panjang dalam pembelajaran bahasa Indonesia kususnya aspek keterampilan berbicara. 
Berdasarkan pengamatan peneliti bahwa pembelajaran di kelas guru telah banyak memberikan contoh-contoh kalimat sebagai bagian untuk membangun karakter peserta didik.

Menumbuhkan kebiasaan anak dalam berfikir dan bertindak dalam hubungan kebiasaan orang Toraja bahwa seorang anak yang tahu menghormati, berbakti, berterimaksih dan bersyukur terhadap nikmat yang diterimanya melalui ucapan kurre sumanga' (terimakasih), tetapi kata kurre sumanga' mengandung arti panjang umur, oleh karena itu jika seorang anak ditinggal mati orang tuanya akan berusaha menguburkannya dengan sebaik-baiknya. Salah satu bakti anak kepada orang tuannnya sebagaimana dalam upacara rambu solo' sebagai kewajiban anak untuk berbakti atau berbuat baik atau rasa hormat atau ungkapan cinta atau ungkapan kasih sayang seorang anak kepada orang tuanya yang telah meninggal. Keyakinan dan perbuatan seperti ini dianggap sebagai perbuatan yang baik dan mulia.

Seperti halnya dalam bahasa Toraja berkedudukan sebagai bahasa sumber, karena unsur-unsur itu beral dari bahasa Toraja masuk dalam bahasa Indonesia. Oleh karena itu peristiwa ini tersebut interferensi bahasa Toraja dalam bahasa Indonesia.

Berdasarkan uraian diatas dapatlah disimpulkan bahwa interferensi adalah penyimpangan salah satu norma bahasa oleh dwibahasawan pada situasi kedwibahasawan. Penyimpangan merupakan unsur-unsur yang dipakai oleh dwibahasawan pada bahasa penyerap, dan unsur serapan tersebut tidak sesuai dengan struktur bahasa penerima. Dengan kata lain unsur serapan itu sudah ada pedanannya dalam bahasa Indonesia.

Alwasilah (1986: 131) mengatakan bahwa interferensi bisa terjadi pada pengucapan, tata bahasa. kosa kata dan makna budaya-baik dalam ucapan maupun tulisan, terutama kalau orang mempelajari bahasa kedua. Sementara Nababan (1986: 35) membagi interferensi menjadi dua bagian, yaitu (1) interferensi perlakuan (performance interference) dan (2) interferensi perlakuan sistemik (systemic interferensi). Dalam interferensi perlakuan ini terdapatadanya pengucapan, baik itu yang bersifat produktif maupun yang bersifat reseptif pada orang berdwibahasa (bilingual). Interferensiperlakuan ini dapat ditemui sewaktu orang masih belajar kedua/asing. Dengan katalain gejala itu tersebut interferensi perkembangan atau interferensi belajar. Sedang pengertian interferensi sistemik adalah pengertian interferensi yang kelihatan dalam bentuk perubahan suatu bahasa dengan unsurunsur, bunyi, atau struktur dari bahasa yang lain. Mekanisme perubahan kebahasaan dalam interferensi sistemik ialah adanya pengutan (borrowing) yang berhubungan eret dengan pungutan kebudayaan (cultural diffusion). 


\section{PENUTUP}

\section{Simpulan}

Pembelajaran bahasa Indonesia di SMA Negeri Toraja Utara sudah diterapkan nilai-nilai budaya Toraja, diantaranya: nilai kasiuluran (kekeluargaan), tengko situru' (kebersamaan), kababsaran (etos kerja), sikamali' (kasih sayang), kapa' patonganan (kerelegiusan), siri'/longko' (rasa malu), umpangke'to Mendadianna (bakti anak kepada orang tua).

\section{Saran}

Disadari bahwa jangkauan penelitian ini terbatas pada nilai kasiuluran (kekeluargaan), tengko situru' (kebersamaan), kababsaran (etos kerja), sikamali' (kasih sayang), kapa' patonganan (kerelegiusan), siri'/longko' (rasa malu), umpangke'to Mendadianna (bakti anak kepada orang tua). Oleh karena itu, disarankan agar dilaksanakan penelitian lanjutan yang membahas nilai-nilai budaya Toraja yang lain.

\section{DAFTAR PUSTAKA}

Al Munawwar, Said Agil Husin. 1993. Fikh Hubungan Antar Agama, Cet. II. Jakarta: Ciputat Press.

Alwasilah. Chaedar. 1986. Sosisologi Bahasa. Bandung: Angkasa.

Depdiknas. 2006. Kurikulum Tingkat Satuan Pendidikan (KTSP). Jakarta: Pusat Kurikulum (Puskur) Depdiknas.

Madjid, Nurcholis. 2000. Masyarakat Religius: Membumikan Nilai-Nilai Islam dalam Kehidupan Masyarakat. Jakarta: Pramadina.

Mudzhar, M. Atho. 2001. Pendekatan Studi Islam dalam Teori dan Praktek, Cet.Ill. Yogyakarta: Pustaka Pelajar.

Syafi'ie, Imam. 1984. Analisis Kesalahan Berbahasa Indonesia dalam Menulis Mahasiswa Tiga IKIP di Jawa. Disertasi tidak Diterbitkan. Malang: FBSIKIPMalang.

Tolla, Achmad. 1996. Kajian Pendekatan Komunikatif dalam Pengajaran bahasa Indonesia di SMU Kotamadya Ujung Pandang. Disertasi. Malang: Pascasarjana IKIP Malang.

Taha, Zainuddin. 2012. Etikel dan dan Kesatunan Berbahasa Berbahasa Bugis. Makalah disajikan pada Kongres Internasional II bahasa -Bahasa Daerah Sulawesi Selatan, tanggal 1-4 Oktober 2012.

Tangdilintin, L.T.2009. Sebuah Panggilan Sejarah dan Budaya. Makassar: Balai Pelestarian Sejarah dan Nilai Tradisional. 